\title{
Do Women's Parliamentary Representation Increase Government Health Spending in Sub-Saharan Africa?
}

\author{
Issa Dianda ${ }^{12^{*}}$ Idrissa Ouedraogo $^{3}$ Aminata Ouedraogo ${ }^{1}$ Jean de Dieu Goumbri ${ }^{1}$ \\ 1. Department of Economics and Management, Thomas Sankara University, Ouagadougou, Burkina Faso
}

2. Ministry of the Environment, Green Economy and Climate Change

3. Department of Economics and Management, University of Yaoundé II, Yaoundé, Cameroon

* Corresponding author: isdianda@yahoo.fr

\begin{abstract}
It is widely recognized in the literature that the increased political participation of marginalized sections of the population allows their interests to be taken into account in public policies. At the same time, in Sub-Saharan Africa, the percentage of women parliamentarians rose from $12.1 \%$ in 2000 to $24 \%$ in 2019. Likewise, health systems are characterized by public underfunding, limited accessibility of health services, and relatively weak maternal and child health indicators. This article evaluates the effect of women's parliamentary representation on government health spending in a sample of 39 sub-Saharan African countries over the period 2000-2017. The estimates made with fixed effects method, random effects method and panel-corrected standard errors method reveal that government health expenditure increases with the proportion of seats in parliament occupied by women. Therefore, this study advocates for the increase of women participation and representation in political and decisionmaking spheres.
\end{abstract}

Keywords: Women political participation, health, government health spending, panel data, sub-Sahara Africa

DOI: $10.7176 / \mathrm{JESD} / 11-18-09$

Publication date:September $30^{\text {th }} 2020$

\section{Introduction}

Health is a component of human capital seen as both an essential ingredient for economic growth and an ultimate goal (Barro, 2013; Sen, 1999). This importance is recognized through the Sustainable development goal (SDG) 3 relating to health which makes Universal health coverage (UHC) a privileged target. Increased levels of public funding of health services from domestic sources are required to achieve this target, given that historically no country has been able to assume UHC without a substantial increase of its health system funding from public resources (Kutzin, 2013).

The pivotal role of health expenditure, in particular the public component, in improving the accessibility of health services and the health of populations has led some authors to study its determinants in order to better implement health policies (Braendle \& Colombier, 2016; Tandon, Fleisher, Li, \& Yap, 2014). Following the pioneering work of Newhouse (1977), which focused on socio-economic and demographic determinants, recent work suggests political determinants. In this vein, Gregorio and Gregorio (2013) recognize that the financing and delivery of health services, by their natures, are political. Furthermore, Kumar (2015) argues that as long as healthcare does not become a political demand and an electoral issue, the situation of a low level of public health care funding will not change.

In this dynamic, it is recognized that increased political participation of the marginalized layers of the society favours the consideration of their interest in public policies (Joshi \& Yu, 2014). Particularly, a better representation of women in decision-making spheres through their accession to political positions allows better consideration of their concerns and those of their children in public policies. Health is a priority for women compared to men because they disproportionately bear the costs of poor health (Bhalotra, Clarke, \& Gomes, 2018; Clayton \& Zetterberg, 2018). When health systems are weak, they run the risk of not receiving adequate prenatal services and of dying during childbirth in the absence of appropriate health infrastructure and qualified health personnel. Besides that, they are the main caregivers for sick adults and children. Therefore, when they have access to political position, they tend to strongly advocate for social spending, including health (Detraz \& Peksen, 2018).

In sub-Saharan Africa (SSA), health systems are characterized by public underfunding, limited accessibility of health services, and relatively weak health indicators. In this region, the level of domestic public health spending is low, despite the progress made recently. Indeed, between 2000 and 2017, the average domestic government 
health expenditure per capita doubled from US\$ 31.24 in Parity purchasing power (PPP) in 2000 to US\$ 69.32 in 2017 (World Bank, 2020). This amount represents 36.11\% of current health expenditure and 1.87\% of Gross domestic product (GDP), against $59.54 \%$ and $5.89 \%$ respectively for the world average. The government expenditure on health, funded from the domestically mobilized resources-to-GDP ratio of $1.87 \%$ is well below the $5 \%$ required to progressing towards UHC (McIntyre, Meheus, \& Røttingen, 2017). Domestic private expenditure and its Out-of-pocket (OOP) component represent respectively $52.73 \%$ and $35.54 \%$ of current health expenditure. The preponderance of OOP spending leads to financial difficulties and even the impoverishment of vulnerable groups, including women. The World Bank (2019) reported that in 2015, around 16 million sub-Saharan Africans ( $1.6 \%$ of the population) has been fallen into poverty due to high OOP payments.

In addition, SSA is the only region in the world where half of the health services deemed essential to achieve UHC are not accessible to the population. Only $43.89 \%$ of these essential services are satisfied while in other regions of the world, at least $52 \%$ of these needs are met for a world average of $65.69 \%$ in 2017 . Similarly, in the region only $59.86 \%$ of births have been attended by skilled health personnel in 2016, while in other regions of the world, this rate is at least $75 \%$ (World Bank, 2020). SSA remains the region with the highest maternal mortality rate (542 per 100,000 live births or thirds of all maternal deaths in the world) and-under-five years mortality rate ( 79.90 per 1,000 live births) (World Bank, 2020; World Health Organization, 2019).

In the same time, the female population of SSA represents $50.11 \%$ of the region population in 2017 (World Bank, 2020). However, the access of this social layer to the spheres of decision making remains a great challenge even if with the wave of democratization in the region, the proportion of women serving in parliaments has improved. In 2019, 24\% of the region's parliamentarians are women, compared to $11 \%$ in 1997 and 12.1\% in 2000 (InterParliamentary Union, 2020). This rate falls short of Aspiration 6, full gender parity, with women occupying at least $50 \%$ of elected public offices at all levels, of the African Union Agenda 2063 (African Union Commission, 2015). In the sample of 39 countries that will be the subject of our analysis, in 2017,11 countries had more than $30 \%$ of women in parliament (lower house) against 6 countries in 2010 and only 1 country in 2000 (Inter-Parliamentary Union, 2020).

The interest of women in health-related issues, coupled with the inadequacies related to maternal and child health and the progress made in terms of women election to parliament in SSA raises a question. What is the effect of the increasing participation of women in parliament on government health expenditure? Our research hypothesis states that the improvement in women's political participation increase government health spending. The rest of the paper is organized into four sections. The second is devoted to the literature review. The methodology is discussed in section three. The fourth section presents and discusses the results. The fifth and last section concludes.

\section{Literature review}

The political participation of women, in particular their rise in decision-making spheres, promotes their interests in public policies. According to power resource theory, the social classes are the main agents of societal change and their balance of power determines the allocation of public expenditure (Hooda, 2016). As collective political actors, women in decision-making area are more committed to advancing women's interests (Ng \& Muntaner, 2018). Likewise, the politics of presence theory posit that there is a close link between the number of women elected and the advancement of women's interests (Phillips, 1995). Thereby, given that health is a preoccupation and priority for women, relative to men, government health spending increases more with the presence of women in decision-making positions and their political influence (Bhalotra, Clarke, \& Gomes, 2018; Detraz \& Peksen, 2018).

This hypothesis is supported by empirical arguments. Miller (2008) reported that the extension of the right to vote to American women citizens is positively associated with an increase in public health care spending in American municipalities. Based on an analysis of the 206 Swiss cantons, Braendle and Colombier (2016) found that the growth rate of cantonal health expenditure increases with the presence of women in parliament. $\mathrm{Ng}$ and Muntaner (2018) reported a positive correlation between women in government and government health spending in Canadian provinces. In the same wave, Clayton and Zetterberg (2018) have shown that the introduction of quotas into the legislative process for the benefit of historically marginalized social layers leads to a change in government priorities in the allocation of public spending. Based on a sample of 139 countries during the peak period of quota adoption and implementation (1995-2012), the authors conclude that quota shocks (large increases in women's parliamentary representation after the introduction of a gender quota) are followed by a substantial increase in government health spending. Another study found that welfare spending is positively associated with the extent of women's presence in the national parliaments in a sample of 97 countries (Detraz \& Peksen, 2018). Mavisakalyan 
(2014) examines the link between women's cabinet representation at the ministerial level and in public health spending in a large sample of 125 countries in the year 2000. The author found that that an increase in the share of women in cabinet is associated with an increase in public health spending as \% of GDP. Unlike the authors previously mentioned, Park (2017) found that women's legislative representation has no significant effect on government healthcare spending in a sample of 22 OECD countries.

This literature, although slightly controversial, reveals that the link between women's political representation and public expenditure has been evaluated in developed countries (Braendle \& Colombier, 2016; Miller, 2008; Ng \& Muntaner, 2018; Park, 2017) and in mixed samples (Clayton \& Zetterberg, 2018; Detraz \& Peksen, 2018; Mavisakalyan, 2014). A little attention has been paid to find the relationship between the two factors in developing countries and particularly in SSA. At the same time, in this region, the increase of women parliamentarian's share is among the most significant political trend of these last years. Therefore, this article fills this literature gap.

\section{Methodology}

This section presents the econometric model specification, variables and data description and estimation method.

\subsection{Empirical model specification, variables and data}

To explore the effect of women's parliamentary representation on government healthcare spending, we propose the following functional form:

$$
D P H E=f(W P R, X)
$$

Equation (1) shows that domestic Government Health Expenditure (DGHE) is a function of women's parliamentary representation and a set of control variables (X). Taking into account the panel dimension and on the basis of empirical work on the determinants of public health spending determinants in Africa and developing countries (Behera \& Dash, 2019; Farag, et al., 2012;Murthy \& Okunade, 2009), we propose a panel data log-log specification as follows:

$$
\begin{aligned}
\log \mathrm{PPHE}_{\mathrm{it}}= & \alpha_{\mathrm{o}}+\alpha_{1} \log W P R_{i t}+\alpha_{2} \operatorname{logPCGDP_{it}}+\alpha_{3} \log T R_{i t}+\alpha_{4} \operatorname{logPop} 65_{i t}+ \\
& \alpha_{5} \log \mathrm{TBI} I_{i t}+\alpha_{6} \operatorname{logPCODAH}{ }_{i t}+\varepsilon_{i t}
\end{aligned}
$$

where $\varepsilon_{i t}$ is the error term; i represents the country and t the period. The coefficients of independent variables are interpreted as elasticities.

DPHE stands for domestic Public Health Expenditure per capita in \$US in PPP (DPHEPC). The control variables include Gross Domestic Product per capita in \$US in PPP (GDPPC), Tax revenue as share of GDP (TR), population aged 65 and above as share of total population (Pop65), the tuberculosis incidence per 100,000 inhabitants (TBI) and the Official Development Assistance for Health Sector Per Capita (PCODAH) \$US in PPP.

We assume that government health spending increase with per capita GDP and fiscal capacity. As an aging and sick population requires more healthcare services and thus more resources, it is hypothesized that the share of elderly population and the incidence of tuberculosis are positively associated to government health spending. Given the weakness of domestic spending and the health systems in SSA, we anticipate that the official development assistance for health sector has a positive effect on domestic public spending on health.

The data are annual and cover 39 SSA countries over the period 2000-2017 due to their availability. The government healthcare spending and the control variables are taken from the world development indicators (World Bank, 2020). The explanatory variable of interest, women's political representation, is approximated by the percentage of female parliamentarians in the national parliament (lower house) and is from the Inter-Parliamentary Union (2020). The fiscal capacity comes from the Government Revenue Dataset of the International Centre for Tax and Development (2020).

\subsection{Estimation method}

To estimate the parameters of the model, we use three different estimation methods. The usual estimators on panel data that are the fixed effects (FE) method and those of the random effects (FE) are used. Although these methods take into account the problem of unobserved heterogeneity, they are valid under the double condition of absence of autocorrelation and the homoscedasticity. However, in general, times-series cross-sectional data violate these assumptions (Avelino, Brown, \& Hunter, 2005). The violation of these assumption renders the coefficient estimates inefficient. Thereby, we use panel-corrected standard errors (PCSE) method proposed by Beck and Katz (1995) 
which deals with these problems, like others studies on the determinants of health spending (Avelino, Brown, \& Hunter, 2005; Gibson, 2018). However, the estimates with the fixed effects and random effects methods are reported for robustness.

\section{Empirical Results}

This section presents the summary Statistics and stylized facts, the baseline results and the robustness checks.

\subsection{Summary Statistics and stylized facts}

Table 1 below summarizes some descriptive statistics of the variables used in the baseline model.

Table 1 : Summary Statistics

\begin{tabular}{llllll}
\hline \hline Variables & Observations & Mean & Std. Dev. & Min & Max \\
\hline \hline WPR & 664 & 17.56 & 11.86 & 0.000 & 63.8 \\
DPHEPC (\$ US in PPP) & 702 & 91.22 & 153.47 & 0.283 & 1085.056 \\
PCGDP (\$US in PPP) & 698 & 4225.857 & 5854.673 & 396.469 & 38407.88 \\
PCODAH (\$US in PPP) & 666 & 28.118 & 32.228 & 0.000 & 223.914 \\
TR (\% of GDP) & 675 & 15.021 & 7.928 & 0.954 & 56.916 \\
TBI (per 100.000 inhabitants) & 666 & 307.1551 & 276.1158 & 7.6 & 1280 \\
Pop65 (\% of total population) & 702 & 3.243 & 1.226 & 1.871 & 10.951 \\
\hline \hline
\end{tabular}

Source: Authors' computation from data

From this table, it appears that during the period, the proportion of women parliamentarians ranged from $0 \%$ in Comoros in 2009 to $63.8 \%$ in Rwanda between 2013 and 2016, for an average of $17.56 \%$.The regional average of per capita government health spending from domestic sources is established at 91.22 \$US in PPP and Per capita GDP at 4225.857 \$US in PPP. The regional per capita official development assistance is 28.118 \$US in PPP. The average amount collected by the countries of the region from taxation representing $15.02 \%$ of GDP. The tuberculosis incidence is 307.15 per 100.000 inhabitants and $3.25 \%$ of SSA people is aged 65 and over.

Table 2 presents the correlation between the variables.

Table 2: Correlation between variables

\begin{tabular}{|c|c|c|c|c|c|c|c|}
\hline & lnDPHEPC & $\operatorname{lnWPR}$ & $\operatorname{lnPCGDP}$ & $\ln \mathrm{PCODAH}$ & $\operatorname{lnTR}$ & $\ln \mathrm{TBI}$ & $\ln$ Pop65 \\
\hline lnDPHEPC & 1 & & & & & & \\
\hline $\operatorname{lnWPR}$ & $0.335^{* * *}$ & 1 & & & & & \\
\hline $\ln P C G D P$ & $0.803 * * *$ & $0.168 * * *$ & 1 & & & & \\
\hline $\operatorname{lnPCODAH}$ & $0.235 * * *$ & $0.273 * * *$ & $0.123 * * *$ & 1 & & & \\
\hline $\ln T R$ & $0.667 * * *$ & $0.377 * * *$ & $0.489 * * *$ & $0.169 * * *$ & 1 & & \\
\hline $\operatorname{lnTBI}$ & -0.001 & $0.125 * * *$ & $-0.123 * * *$ & $0.342 * * *$ & $0.065^{*}$ & 1 & \\
\hline $\ln$ Pop65 & $0.548 * * *$ & $0.136 * * *$ & $0.535 * * *$ & $-0.151 * * *$ & $0.409 * * *$ & $-0.307 * * *$ & 1 \\
\hline
\end{tabular}

*** and * mean significant correlation at $1 \%$ and $10 \%$ level respectively.

Source: Authors' computation from data

It appears that per capita government health spending and the share of women parliamentarian are positively and significantly corelated at $1 \%$ level. To provide an illustration, figure 1 below confirms the positive relationship between the share of women parliamentarian and the level of government health spending. 


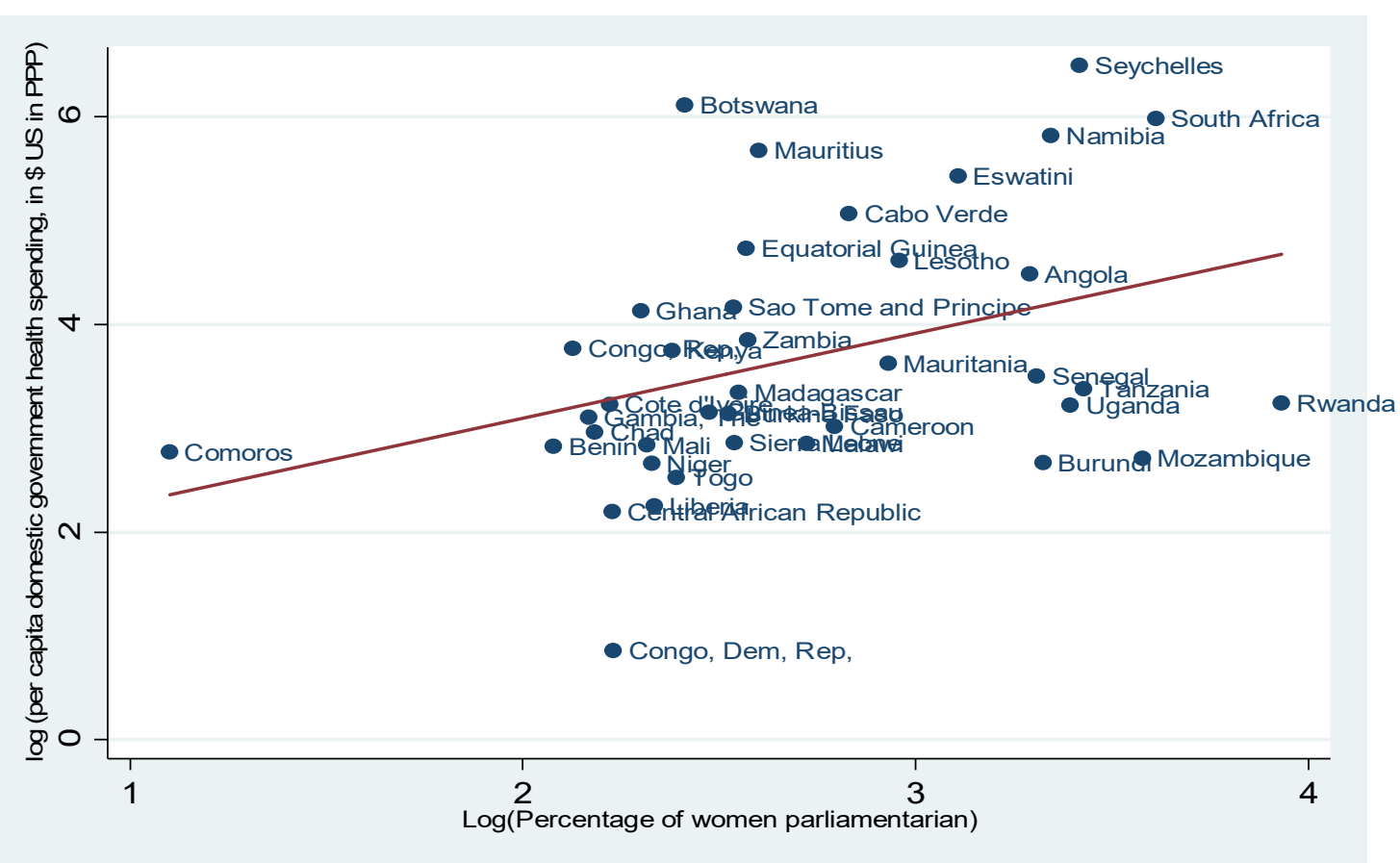

Figure 1: share of women parliamentarian and domestic government health spending in 39 SSA countries during 2000-2017

Likewise, per capita GDP, per capita official development aid for health, tax capacity and elderly population are all positivity and significantly corelated with per capita domestic government health spending at $1 \%$ level. The correlation coefficient between per capita government health spending and tuberculosis incidence is negative but not significant. However, correlation analysis does not provide information on causality, hence the need for a more rigorous empirical analysis.

\subsection{Baseline Results}

The results of baseline estimates are shown in Table 3.

The estimates are made in two stages. The parliamentarian representation of women is included as the only explanatory variable at first. Secondly, the control variables are added. From the table, it emerges that the explanatory variables jointly and significantly explain the change in government spending on health, as the Chi2statistics are statistically significant at $1 \%$ level $(\mathrm{p}$-value $<0.00)$. In addition, The R-Squared for the estimates with all variables is between for 0.79 and 0.90 , suggesting that the independent variables capture between $79 \%$ and $90 \%$ of the variations in public health expenditures.

Results in Table 3 show that when the parliamentarian representation of women is introduced as the only explanatory variable, its coefficient is positive and significant at $1 \%$ level of significance.

A 10 percent increase of the share of seats in parliament held by women is associated with an increase in domestic government health expenditure per inhabitant of between $2.92 \%$ and $4 \%$. The coefficient of the parliamentary representation of women remains significant at $1 \%$ with the addition of the control variables in the model even if its value decreases. Indeed, an increase in the share of women parliamentarian of $10 \%$ translates, all things being equal, by an increase in domestic public health spending per inhabitant between $1.49 \%$. and $1.92 \%$.

This result reveals that the interests of women, especially the prioritization of the health sector, are taken into account in public policies as much as they are represented in parliament. It supports the argument that close participation of marginalized sections of society in the political sphere allows them to better articulate their interests so that they are taken into account in decision-making (Hooda, 2016; Joshi \& Yu, 2014). The result is similar to those obtained with the fixed and random effects methods and reveals that the inclusion of women in decision-making spheres through parliaments is favourable to the increase in public health spending in SSA. This conclusion is in accordance with the results in earlier studies in developed countries (Braendle \& Colombier, 2016; Miller, 2008; Ng \& Muntaner, 2018) and in mixed sample of developed and developing countries (Clayton \& Zetterberg, 2018; Detraz \& Peksen, 2018; Mavisakalyan, 2014). However, our result contradicts those obtained by 
Park (2017) who found that women's legislative representation does not affect the government healthcare spending.

Table 3: Baseline results

\begin{tabular}{|c|c|c|c|c|c|c|}
\hline \multirow{2}{*}{$\begin{array}{l}\text { Variables } \\
\text { log(Women Parliamentarian } \\
\text { representation) }\end{array}$} & \multicolumn{2}{|c|}{ Fixed Effects Model } & \multicolumn{2}{|c|}{ "Random Effects Model } & \multicolumn{2}{|c|}{$\begin{array}{c}\text { Panel-corrected standard } \\
\text { errors method }\end{array}$} \\
\hline & $\begin{array}{l}\mathbf{0 . 3 9 6}^{* * *} \\
(0.000)\end{array}$ & $\begin{array}{l}\mathbf{0 . 1 9 2 * * *} \\
(0.000)\end{array}$ & $\begin{array}{l}\mathbf{0 . 4 0 0 * * *} \\
(0.000)\end{array}$ & $\begin{array}{l}\mathbf{0 . 1 5 9 * * *} \\
(0.000)\end{array}$ & $\begin{array}{l}\mathbf{0 . 2 9 2 * * *} \\
(0.000)\end{array}$ & $\begin{array}{l}\mathbf{0 . 1 4 9 * * *} \\
(0.000)\end{array}$ \\
\hline $\log ($ Per capita GDP) & & $\begin{array}{l}0.625^{* * * *} \\
(0.000)\end{array}$ & & $\begin{array}{l}0.986 * * * \\
(0.000)\end{array}$ & & $\begin{array}{l}0.822 * * * \\
(0.000)\end{array}$ \\
\hline $\log$ (Per Capita Health Aid) & & $\begin{array}{l}0.018 \\
(0.496)\end{array}$ & & $\begin{array}{l}0.104 * * * \\
(0.000)\end{array}$ & & $\begin{array}{l}0.071 * * * \\
(0.000)\end{array}$ \\
\hline $\log$ (Tax Revenues) & & $\begin{array}{l}0.168 * \\
(0.059)\end{array}$ & & $\begin{array}{l}0.368 * * * \\
(0.000)\end{array}$ & & $\begin{array}{l}0.363 * * * \\
(0.000)\end{array}$ \\
\hline $\log ($ Tuberculosis Incidence) & & $\begin{array}{l}-0.044 \\
(0.620)\end{array}$ & & $\begin{array}{l}0.040 * * \\
(0.028)\end{array}$ & & $\begin{array}{l}0.112 * * * \\
(0.000)\end{array}$ \\
\hline $\log$ (Population 65) & & $\begin{array}{l}0.386 \\
(0.135)\end{array}$ & & $\begin{array}{l}0.898 * * * \\
(0.000)\end{array}$ & & $\begin{array}{l}1.046^{* * * *} \\
(0.000)\end{array}$ \\
\hline Constant & $\begin{array}{l}2.590 * * * \\
(0.000)\end{array}$ & $\begin{array}{l}-2.480 * * \\
(0.024)\end{array}$ & $\begin{array}{l}2.543 * * * \\
(0.000)\end{array}$ & $\begin{array}{l}-7.904 * * * \\
(0.000)\end{array}$ & $\begin{array}{l}2.619 * * * \\
(0.000)\end{array}$ & $\begin{array}{l}-6.106 * * * \\
(0.000)\end{array}$ \\
\hline R Squared & 0.112 & 0.793 & 0.112 & 0.848 & 0.867 & 0.90 \\
\hline Fisher Test & 0.000 & 0.000 & & & & \\
\hline Wald Test P-Value & & & 0.000 & 0.000 & 0.000 & 0.000 \\
\hline Observations & 663 & 609 & 663 & 609 & 663 & 609 \\
\hline countries & 39 & 39 & 39 & 39 & 39 & 39 \\
\hline
\end{tabular}

Figures in parentheses are p-values; ***, ** and *denote respectively significance at $1 \% .5 \%$ and $10 \%$.

Source: Authors estimation

From the estimates shown in Table 3, it appears that the coefficients associated with the control variables have the expected sign and are statistically significant at $1 \%$ threshold. The coefficient of income per capita is positive $(0.82)$ and significant at 1\% level. An increase in per capita income of $10 \%$ translates into an increase in Government health expenditure per capita of $8.22 \%$, all other things being equal. This result reflects the fact that the more countries develop, the more they are able to devote more resources to the health of their populations. The improvement in the level of income is associated with a quantitative and qualitative increase in the demand for health services. Moreover, the estimate reveals that income elasticity of public health expenditure is less than 1 , meaning that healthcare is a necessity in SSA. As healthcare is a necessity, the intervention of governments in the financing of the health system and in the provision of health care is essential to facilitate the access of disadvantaged sections of the society to a better-quality health service. This result is in line with that obtained by Farag et al. (2012).

The estimate reveals that health aid and fiscal capacity are positively and significantly associated with government health spending. This result suggests that in SSA, health aid is not fungible. The improvement of fiscal capacity gives more opportunity to governments to devote more resources to the health of their citizens. This result is in accordance with those of previous studies (Behera \& Dash, 2019; Hooda, 2016). In line with theoretical expectations, the coefficients of tuberculosis incidence and the share of elderly population are both positive and significant at $1 \%$ level. The government health spending increase with the tuberculosis incidence and the elderly population. More resources are needed to care for a sick population (Galama, 2015). Specifically, the treatment of infectious diseases such as tuberculosis is the responsibility of government given the negative externalities they generate through the contagion of a healthy person by a patient. Likewise, the elderly population is very vulnerable 
to disease, demands more health services and requires more frequent and more costly medical treatment than younger people (McGuire, 2010).

\subsection{Robustness Check}

In this subsection, additional analyses are conducted in order to test the robustness of the result obtained in the basic model to the use of alternatives dependent variables. To this end, the domestic government health spending as share of health spending, as share of GDP and as share of government spending are used. The results of the estimates are reported in Table 4 below.

As it is evident in the Table 4, the coefficient of Women Parliamentarian representation is positive and significant at $1 \%$ level in the estimates with all three alternative dependent variables. Indeed, government health spending as share of health spending and as percentage of government spending went up respectively from $0.7 \%$ to $1.36 \%$ and $0.78 \%$ to $1.27 \%$ when the share of seats in parliament held by women increased by $10 \%$. Likewise, for $10 \%$ increase in share of women parliamentarian, the share of government health spending in GDP increases from $0.99 \%$ to $1.27 \%$.

Table 4: Robustness Checks with alternative dependant variables

\begin{tabular}{|c|c|c|c|c|c|c|c|c|c|}
\hline \multirow{2}{*}{$\begin{array}{l}\text { Government } \\
\text { Spending as }\end{array}$} & \multicolumn{3}{|c|}{ \% Health Spending } & \multicolumn{3}{|c|}{ \% of GDP } & \multicolumn{3}{|c|}{ "\% Government Spending } \\
\hline & FE & $\mathbf{R E}$ & PCSE & FE & $\mathbf{R E}$ & PCSE & FE & RE & PCSE \\
\hline (Women & $0.136 * * *$ & $0.133 * * *$ & $0.074 * * *$ & $0.147 * * *$ & $0.142 * * *$ & $0.099 * * *$ & $0.127 * * *$ & $0.127 * * *$ & $0.078 * * *$ \\
\hline Parliamentarian & $(0.000)$ & $(0.000)$ & $(0.000)$ & $(0.001)$ & $(0.000)$ & $(0.000)$ & $(0.001)$ & $(0.001)$ & $(0.000)$ \\
\hline \multicolumn{10}{|l|}{ Representation) } \\
\hline \multirow[t]{3}{*}{$\log ($ Per capita GDP) } & 0.081 & $0.147 * * *$ & 0.091 & -0.125 & -0.080 & -0 . & $-0.150 *$ & $-0.117 * *$ & $-0.100 * *$ \\
\hline & $(0.311)$ & $(0.006)$ & & $(0.187)$ & $0.162)$ & $143 * * *$ & $(0.083)$ & $0.036)$ & $(0.028)$ \\
\hline & & & $(0.004)$ & & & $(0.000)$ & & & \\
\hline $\log ($ Per & -0 . & - & -0.019 & 0.003 & - & $0.084^{* * *}$ & -0.023 & -0.018 & $0.040^{* *}$ \\
\hline \multirow[t]{2}{*}{ Health Aid) } & $121 * * *$ & $0.125^{* * *}$ & $(0.197)$ & $(0.897)$ & $0.125 * * *$ & $(0.000)$ & $(0.325)$ & $(0.392)$ & $(0.027)$ \\
\hline & $(0.000)$ & $(0.000)$ & & & $(0.000)$ & & & & \\
\hline \multirow[t]{3}{*}{$\log ($ Tax Revenues) } & $-0.145^{*}$ & -0.059 & $0.115^{* *}$ & 0.081 & 0.009 & $0.388 * * *$ & - & - & - \\
\hline & $(0.045)$ & $(0.382)$ & $(0.012)$ & $(0.340)$ & $(0.696)$ & $(0.000)$ & $0.463 * * *$ & $0.352 * * *$ & $0.158 * * *$ \\
\hline & & & & & & & $(0.000)$ & $(0.000)$ & $(0.003)$ \\
\hline \multirow{2}{*}{$\begin{array}{l}\log (\text { Tuberculosis } \\
\text { Incidence) }\end{array}$} & 0.022 & $0.105^{* *}$ & $0.112 * * *$ & 0.041 & $0.122 * *$ & 0.002 & 0.016 & $0.122 * *$ & $0.096^{* * *}$ \\
\hline & $(0.758)$ & $(0.023)$ & $(0.000)$ & $(0.626)$ & $(0.014)$ & $(0.938)$ & $(0.830)$ & $(0.012)$ & $(0.002)$ \\
\hline \multirow[t]{2}{*}{$\log ($ Population 65) } & $0.392 *$ & $0.510^{* * *}$ & $0.552 * * *$ & $0.528^{*}$ & $0.758 * * *$ & $0.802 * * *$ & $0.823 * * *$ & $0.916^{* * *}$ & $0.781 * * *$ \\
\hline & $(0.062)$ & $(0.001)$ & $(0.000)$ & $(0.033)$ & $(0.000)$ & $(0.000)$ & $(0.000)$ & $(0.000)$ & $(0.000)$ \\
\hline \multirow[t]{3}{*}{ Constant } & $2.515 * * *$ & $1.213 * *$ & $1.014 * * *$ & -0.033 & - & $0.839^{* * *}$ & $2.950 * * *$ & $1.724 * * *$ & $1.348 * * *$ \\
\hline & $(0.005)$ & $(0.018)$ & $(0.000)$ & $(0.975)$ & $1.432 * * *$ & $(0.000)$ & $(0.002)$ & $(0.001)$ & $(0.000)$ \\
\hline & & & & & $(0.008)$ & & & & \\
\hline R Squared & 0.134 & 0.255 & 0.937 & 0.270 & 0.364 & 0.249 & 0.014 & 0.079 & 0.771 \\
\hline Fisher Test & 0.000 & & & 0.006 & & & 0.000 & & \\
\hline Wald Test P-Value & & 0.000 & 0.000 & & 0.000 & 0.000 & & 0.000 & 0.000 \\
\hline Observations & 609 & 609 & 609 & 609 & 609 & 609 & 609 & 609 & 609 \\
\hline countries & 39 & 39 & 39 & 39 & 39 & 39 & 39 & 39 & 39 \\
\hline
\end{tabular}

Source: Authors estimation. 


\section{Conclusion}

The political ascension of women in SSA is one of the major trends in the socio-political field in recent years. This study has evaluated the effect of the increasing participation of women in parliaments on government health expenditure in a sample of 39 SSA countries over the period 2000-2017.

The estimates are made with fixed effects method, random effects method and panel-corrected standard errors method. From these estimates, it emerges that per capita domestic government health spending, domestic government health spending as a percentage of GDP, domestic government health spending as a proportion of health spending and domestic government health spending as share of government spending increases with the proportion of seats in parliament occupied by women. This result confirms the hypothesis according to which an increased political participation of marginalized layers of the population allows their concerns to be taken into account in public policies. Moreover, per capita GDP, official development aid to health per capita, fiscal capacity, the proportion of the population aged 65 and over and the incidence of tuberculosis positively affect government health spending.

The analysis suggests that efforts in terms of public investments in health systems to upgrade them in order to ensure accessible and quality healthcare, especially for the benefit of the poor, with a view to tend towards universal health coverage, go through the political promotion of women. Therefore, this article advocates for the increase of their participation and representation in political and decision-making spheres.

\section{References}

African Union Commission. (2015). Agenda 2063: The Africa we want. Addis Ababa, Ethiopia.

Avelino, G., Brown, D. S., \& Hunter, W. (2005). The effects of capital mobility, trade openness, and democracy on social spending in Latin America, 1980-1999. American Journal of Political Science, 49(3), 625-641. https://doi.org/10.1111/j.1540-5907.2005.00146.x

Barro, R. J. (2013). Health and economic growth. Annals of Economics and Finance, 14(2(A)), 305-342.

Beck, N. L., \& Katz, J. N. (1995). What to do (and not to do) with time series cross-section data. American Political Science Review, 89(3), 634-647. https://doi.org/10.2307/2082979

Behera, D. K., \& Dash, U. (2019). Impact of macro-fiscal determinants on health financing: Empirical evidence from low-and middle-income countries. Global Health Research and Policy, 4(21), 1-13. https://doi.org/10.1186/s41256-019-0112-4

Bhalotra, S., Clarke, D., \& Gomes, J. (2018). Maternal Mortality and Women's Political Participation. WIDER Working Paper No. 2018/58), UNU-WIDER.

Braendle, T., \& Colombier, C. (2016). What drives public health care expenditure growth? Evidence from Swiss cantons, 1970-2012. Health Policy, 120(9), 1051-1060. https://doi.org/10.1016/j.healthpol.2016.07.009

Clayton, A., \& Zetterberg, P. (2018). Electoral Gender Quotas and Government Spending Priorities Worldwide. Journal of Politics, 80(3), 916-932. https://doi.org/10.1086/697251

Detraz, N., \& Peksen, D. (2018). "Women friendly" spending? Welfare spending and women's participation in the economy and politics. Politics \& Gender, 14(2), 137-161. https://doi.org/10.1017/S1743923X17000253

Farag, M., NandaKumar, A., Wallack, S., Hodgkin, D., Gaumer, G., \& Erbil, C. (2012). The income elasticity of health care spending in developing and developed countries. International Journal of Health Economics and Management, 12(2), 145-162. https://doi.org/10.1007/s10754-012-9108-z

Galama, T. J. (2015). A contribution to health-capital theory. Working Paper Series, University of Chicago, Human Capital and Economic Opportunity Global Working Group, Economics Research Center, Chicago. http://dx.doi.org/10.2139/ssrn.2601121

Gibson, C. W. (2018). Determinants of state spending patterns in Arab League member states: A post-arab spring analysis, 1996-2014. International Journal of Politics, Culture, and Society, 1-26. https://doi.org/10.1007/s10767018-9293-y

Gregorio, L. E., \& Gregorio, D. I. (2013). Polity and health care expenditures: The association among 159 nations. Journal of Epidemiology and Global Health, 3(1), 49-57. https://doi.org/10.1016/j.jegh.2012.12.007

Hooda, S. K. (2016). Determinants of public expenditure on health in India: A panel data analysis at sub-national level. Journal of Quantitative Economics, 14(2), 257-282. https://doi.org/10.1007/s40953-016-0033-8 
ICTD - International Centre for Tax and Development. (2020). Government Revenue Dataset.

Inter-Parliamentary Union. (2020). Statistical archive: Women in national parliaments. https://data.ipu.org/women-averages

Joshi, D. K., \& Yu, B. (2014). Political determinants of public health investment in China and India. Asian Politics \& Policy, 6(1), 59-82. https://doi.org/10.1111/aspp.12087

Kumar, R. (2015). Lack of social or political demand for good health care in India: impact on unfolding universal health coverage. Journal of Family Medicine and Primary Care, 4(1), 1-2. https://doi.org/10.4103/22494863.152234

Kutzin, J. (2013). Health financing for universal coverage and health system performance: Concepts and implications for policy. Bulletin of the World Health Organization, 91(8), 602-611. http://dx.doi.org/10.2471/BLT.12.113985

Mavisakalyan, A. (2014). Women in cabinet and public health spending: evidence across countries. Economics of Governance, 15, 281-304. http://dx.doi.org/10.1007/s10101-014-0141-x

McGuire, J. W. (2010). Wealth, health, and democracy in East Asia and Latin America. Cambridge and New York: Cambridge University Press.

McIntyre, D., Meheus, F., \& Røttingen, J.-A. (2017). What level of domestic government health expenditure should we aspire to for universal health coverage? Health Economics, Policy and Law, 12(2), 125-137. https://doi.org/10.1017/S1744133116000414

Miller, G. (2008). Women's suffrage, political responsiveness, and child survival in American history. The Quarterly Journal of Economics, 123(3), 1287-1327. https://doi.org/10.1162/qjec.2008.123.3.1287

Murthy, V. N., \& Okunade, A. A. (2009). The core determinants of health expenditure in the African context:Some econometric evidence for policy. Health Policy, 91(1), 57-62. https://doi.org/10.1016/j.healthpol.2008.10.001

Newhouse, J. P. (1977). Medical-care expenditure: A cross-national survey. The Journal of Human Resources, 12(1), 115-125. https://doi.org/10.2307/145602

$\mathrm{Ng}$, E., \& Muntaner, C. (2018). The effect of women in government on population health: An ecological analysis among Canadian provinces, 1976-2009. SSM - Population Health, 141-148. https://doi.org/10.1016/j.ssmph.2018.08.003

Park, S. S. (2017). Gendered representation and critical mass: Women's legislative representation and social spending in 22 OECD countries. Sociological Perspectives, 1-18. https://doi.org/10.1177/0731121417710458

Phillips, A. (1995). The politics of presence. Clarendon Press.

Sen, A. (1999). Santé et développement. Allocution d'orientation à la Cinquante-Deuxième Assemblée mondiale de la Santé, Organisation Mondiale de la Santé, Genève.

Tandon, A., Fleisher, L., Li, R., \& Yap, W. A. (2014). Reprioritizing government spending on health: Pushing an elephant up the stairs? WHO South-East Asia Journal of Public Health, 3(3-4), $206-212$. https://doi.org/10.4103/2224-3151.206742

World Bank. (2019). Financial Protection in Health Global Monitoring Data - 2019. Washington, D C.

World Bank. (2020). World development indicators. Whasington, DC.

World Health Organization. (2019). Trends in maternal mortality 2000 to 2017: estimates by WHO, UNICEF, UNFPA, World Bank Group and the United Nations Population Division. Geneva. 


$\begin{array}{lll}\begin{array}{l}\text { Appendix 1.: List of Countries } \\ \text { Angola }\end{array} & \text { Equatorial Guinea } & \text { Mozambique } \\ \begin{array}{l}\text { Benin } \\ \text { Botswana }\end{array} & \begin{array}{l}\text { Eswatini } \\ \text { Gambia }\end{array} & \text { Namibia } \\ \text { Burkina Faso } & \text { Giger } \\ \text { Burundi } & \text { Guinea-Bissau } & \text { Rwanda } \\ \text { Cabo Verde } & \text { Kenya } & \text { Senegal } \\ \text { Cameroon } & \text { Lesotho } & \text { Seychelles } \\ \text { Central African Republic } & \text { Liberia } & \text { Sierra Leone } \\ \text { Chad } & \text { Madagascar } & \text { South Africa } \\ \text { Comoros } & \text { Malawi } & \text { Tanzania } \\ \text { Democratic Republic of Congo } & \text { Mali } & \text { Togo } \\ \text { Republic of Congo } & \text { Mauritania } & \text { Uganda } \\ \text { Cote d'Ivoire } & \text { Mauritius } & \text { Zambia }\end{array}$

